\title{
READERS
Insight
}

\author{
Journal of Economic Info (JEI) \\ ISSN:2313-3376 \\ www.readersinsight.net/jei
}

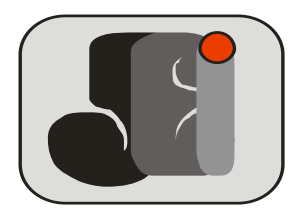

\section{Mapping of Patient Distribution in ICU Room of Regional General Hospital of Meranti Islands in 2018}

\author{
Wen Via Trisna*1, Ulil Kholili² \\ ${ }^{1,2}$ STIKes Hang Tuah Pekanbaru \\ *Corresponding author: wenvia@htp.ac.id
}

\begin{abstract}
Geographic Information System (GIS) is a computer-based information system used to process and strore geographic data or information. One of the health services in a hospital is Intensive Care Unit (ICU). One of the decision making in RSUD of Meranti Islands Municipality is based on the hospital activity report. The purpose was to map the patient distribution by using geographic information system application to prodce reporting using a map. The type of this research was qualitative descriptive. The research results based on the ICU patient distribution showed that the highest patient visit based on the sub-district is from Tebing Tinggi. Based on the gender, the most frequently treated patient is male. In the age category, the highest patient visit is elderly of 44 people, and the lowest children age group of 3 people. Based on the distribution, it can be concluded that the procedure of BPJS patient is appropriate and has similar procedure with general patient and SKTM patient. The suggestion includes creating patient distribution mapping based on the diesases to allow us to see the general patient distribution in ICU, which should be provided with excellent services, so that the patients satisfied with the services provided.
\end{abstract}

Keywords: Mapping of ICU Patients in RSUD of Meranti Islands Municipality
ARTICLE INFORMATION

Received: 10 Dec 2018

Revised: 10 Jan 2019

Accepted: 31 Jan 2019

DOI: $10.31580 /$ jei.v6i1.486

\section{INTRODUCTION}

Hospital as one of the health service providers which has a referral function must be able to provide professional and quality ICU services by prioritizing the patient safety. Decree of Minister of Health of the Republic of Indonesia Number: 1778/ MENKES/ SK/ XII/ 2010 Intensive Care Unit (ICU) is a part of an independent hospital (installation under the service director) with specialized staff and equipment specifically for the treatment of patients suffering lifethreatening or potentially life-threatening illnesses, injuries or complications with dubious prognosis. The Intensive Care Unit (ICU) is part of a critical service category of hospital buildings, in addition to surgical and emergency installations.

At first, the treatment at the ICU was for patient post-operatives. However, after the discovery of various recorders (monitors) and the use of ventilators to overcome breathing, ICU is also equipped with monitors and ventilators. Besides that, with dialysis method, the separation of toxins from the serum including the high urea levels so that the ICU is also equipped with hemodialysis. Outpatient and inpatient care is a hospital service which can produce information to speed up and facilitate information generated systematically, dynamically, precisely and accurately. It can be analyzed by presenting 2 data into images, graph tables, maps or epidemiological narratives. According to Najmah (2015), Epidemiology is a study of the distribution and determinants related to health problems in a particular area or specific events in a population and application of research, which is as an effort to prevent and control the health problems. Therefore, we need facilities which can provide convenience for policy makers, visualize health problems in relation to human and environmental resources so that they can effectively. and efficiently monitor and process the disease and public health program. One of the facilities is the Geographic Information System (GIS).

Through the Geographic Information System (GIS), health information can be presented in an informative and interactive manner. Geographic Information System (GIS) is a computer-based information system which is used to process and store geographic data or information. In general, GIS (Geographic Information System) is a component consisting of hardware, software, geographic data and human resources which work together effectively to enter, store, repair, update, manage, manipulate, integrate, analyze and display data in a geographical information. GIS has the ability to connect various data at one specific point on earth, combine them, analyze and finally map the results (GIS Aceh Nias Consortium, 2007).

Based on the results of the study conducted by Herianti in 2015, she stated that the making of thematic maps regarding information on the distribution of the number of general patients admitted to hospital in the yellow space was obtained from the data of patients entering the yellow space in 2015. From this data, there were 1894 patients. The data was then sorted according to the payment method, and it was obtained as many as 941 patients who use their own fees or are called general patients. Data with a total of 941 patients recorded their respective addresses.

Regional Public Hospital (RSUD) of Meranti Islands District is one of the hospitals located on the Dorak Road in Tebing Tinggi Subdistrict, Meranti Islands District, Riau Province. One of the decision making in RSUD of Meranti Islands District is based on a report on hospital activities. The total capacity of beds available in the ICU is 4 beds. Meanwhile, the report on the number of patient visiting the ICU room for the last 6 months in 2017 is 69 patients. It is necessary to present a report in the form of a map. By presenting in the form of a map, it will provide a clearer picture of the patient's distribution in the 
ICU room based on the method of payment. Given the importance of presenting reports in the form of map, the researcher is interested in conducting a research on "Mapping the Distribution of Patients in ICU Rooms at Meranti Islands Hospital in 2018".

\section{LITERATUREREVIEW}

\section{Thematic Map}

A map is a description of a part or the whole earth located above or below the surface and is presented in a flat plane at a specific scale and projection systematically. Since it is limited by scale and projection, the map will never be as complete and as detailed as the earth Therefore, it is necessary to simplify and select the elements to be displayed on the map (GIS Aceh Nias Consortium, 2007).

The role of map in GIS is considered important because other than as the data sources, map is also a medium to help people understand the area to be worked on. In a map, there must be a scale. The scale is a comparison between the distance in the map and the actual distance, so that we can know the conditions on the actual field. Thematic map is map which illustrates the geographical concept, such as population, density, climate, transfer of goods and others. In order to form a thematic map on ArcView, legend can be used. Forms of gradual colors and gradual symbols present the levels or ranking of the numerical data. Gradual color legends can be used for data areas, while the gradual symbols can be used for point and line data.

\section{GIS}

Data to be handled in GIS (geographic information system) is spatial data, which is a geographically oriented data, has a specific coordinate system as its reference base and has two important parts which make it different from other data. Geographic Information System (GIS) is a computer-based information system used to process and store geographic data or information (GIS of Aceh Nias Consortium, 2007). In general, GIS (Geographic Information System) is a component consisting of hardware, software, geographic data and human resources which work together effectively to enter, store, repair, update, manage, manipulate, integrate, analyze and display data in a geographical information. GIS has the ability to connect various data at a certain point on earth, combine them, analyze and finally map the results.

GIS can be described in several sub-systems, those are; (1) Input, which is the stage of preparation and collection of the spatial data and attributes from various sources. In this stage, conversion of analog data to the appropriate digital format is also carried out. (2) Manipulation, which is the adjustment of the data entered for further processing, for example: scale equations, changing the projection system, generalizations, etc. (3) Data Management, which is using the Database Management System (DBMS), to help store, organize, and process the data (4) Query, which is searching the data using more than one layer, aims to provide information for the analysis, and obtain the desired data (5) Analysis, is the ability to analyze the spatial data in order to obtain new information by making a "What if" scenario model. One analytical facility which is widely used is overlay analysis, and (6) Visualization, which is the presentation of results in the form of new information or existing databases in the form of softcopy or hardcopy in the form of: map, table, graph, and etc.

\section{Map Making using Arcview}

Stages in map-making using Arcview application are:

1. Open the Arcview 3.3 application

2. Click views, select as a blank project

3. On views, click new

4. Then, select the file menu, click extensions, in available extensions select JPEG (Image Support Legend Tools) to open the file with type of JPEG, click ok.
5. In the view menu, select properties, scale the map on map units and distance units, replaced with the centimeters scale, then click ok. The view appearance has been completed

6. Select add theme, in the source types data, change the image format of the data source, then open the image file for the basis of making a map

7. In the view menu, select new theme, in the feature types, select polygons to create a map pattern and divide the area based on the map.

8. Next, draw a map pattern with vertex tools according to the base of the map image point from point to form a map pattern.

9. After the map pattern is finished, click view properties, change the background color into transparent.

10. Click attributes on the map, give a new column for naming the map area.

11. Select the theme menu, click auto-label. Thus, the name of the region that has been written will appear based on the region

12. Make a path on the map, click new theme, select line, click ok

13. Same as the region name, giving the road name has been made by clicking attributes in line, give a new column for naming the map road, do not forget to create a road pattern with draw line tools.

14. Select the menu theme, click auto-label, then the inputted street name will appear based on the path

15. Make a color comparison to find out its amount and its distribution in each region, select Legend Editor Properties, in Legend Type select graduated color, click Apply, then a histogram prosentase of the population will appear, so that it can conclude the height of the map and in the legend editor, select point, therefore, its distribution with its points illustration will appear on the map. Thus, it can be concluded that more points means that the distribution on the map is higher.

\section{METHODOLOGY/MATERIALS}

The research method used is descriptive qualitative. This research is carried out by taking steps start from collecting the data, making conclusions, and reporting. The study was conducted at the Regional Public Hospital of Meranti Islands. The informants in this study are 3 people. The data collection technique used is Non Static technique. The instruments used in the research are guidelines for observation, stationery, laptop, Gis ArcView, Microsoft Word, and Microsoft Excel. The processing data was conducted using triangulation of sources, methods and data. In this research, the data analysis used was qualitative analysis.

\section{RESULTS AND FINDINGS}

\section{Observation Result}

The results of the observation conducted by researcher in the ICU Room and Medical Record at the Meranti Islands District Hospital can be seen from the following table:

Table 1. Observation Result on Mapping the Distribution of Patients in the ICU Room at Meranti Islands District Hospital in 2018

\begin{tabular}{|c|c|c|c|c|c|c|c|c|c|}
\hline \multirow{2}{*}{ No } & \multirow{2}{*}{ Sub-Districts } & \multirow{2}{*}{$\begin{array}{l}\text { Number } \\
\text { of People }\end{array}$} & \multicolumn{4}{|c|}{ Age Group } & \multicolumn{2}{|c|}{ Gender } & \multirow{2}{*}{ Total } \\
\hline & & & $\mathbf{T}$ & C & $\mathbf{T A}$ & $E$ & M & $F$ & \\
\hline 1 & Tebing Tinggi & 76.763 & 13 & 2 & 86 & 28 & 33 & 24 & 57 \\
\hline 2 & Pulau merbau & 13.987 & 4 & & 4 & 4 & 5 & 7 & 12 \\
\hline 3 & $\begin{array}{l}\text { Tebing } \\
\text { timur }\end{array}$ & 25.887 & 5 & & 1 & 3 & 7 & 1 & 8 \\
\hline 4 & Merbau & 47.370 & 1 & & 2 & 3 & 2 & 4 & 6 \\
\hline 5 & Rangsang & 28.106 & 4 & & 2 & 2 & 5 & 3 & 8 \\
\hline 6 & $\begin{array}{l}\text { Tebing } \\
\text { barat }\end{array}$ & 15.126 & 3 & & 11 & 2 & 3 & 5 & 8 \\
\hline
\end{tabular}




\begin{tabular}{lllllllllll}
\hline 7 & Tasik putri puyu & 17.919 & 1 & & 1 & 0 & 2 & 2 \\
8 & $\begin{array}{l}\text { Rangsang } \\
\text { pesisir }\end{array} \quad 10.778$ & 1 & & 1 & 2 & 2 & 2 & 4 & 6 \\
9 & Rangsang barat 29.770 & 1 & 1 & 2 & & 2 & 2 & 4 \\
\hline
\end{tabular}

Description of age group:

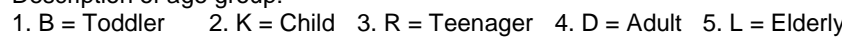

\section{Interview Result}

The Distribution of BPJS PATIENTS IN ICU ROOM IN REGIONAL Public Hospital of MERANTI ISLANDS DISTRICT

Based on the result of research conducted at the Meranti Islands Regional General Hospital, it is known that for the distribution of BPJS patients, there is no difficulty in obtaining facilities in the ICU room if the patient's requirements meet the procedure and there is no limit on the number of BPJS patients. BPJS patients or general patients have no limitations or differences in getting facility services in the ICU. It is just that they do not get facilities if the ICU room is full.

Based on the result of research from Luh Utu Ika Juliantini (2013), the number of health care providers (PPK 1) registered at PT. askes (Persero) Denpasar branch is PPK I which will serve all participants of the national social security system (SJSN) in 2014 in Denpasar city. Possibly, this number will be added to be able to serve all SJSN participants. This PPK I must meet the criteria to pass the selection as PPK I PT. Askes (Persero). In this case, PPK I registered at PT. Jamsostek also has the opportunity to become PPK I PT. Askes (Persero). By using the Geographic Information System (GIS) application, PPK I Jamsostek and PPK I PT. Askes (Persero) is presented as in the form of a map. BPJS is a Social Security Organizing Agency that has a legal entity formed to organize a Social Security Program. Based on article 5 paragraph (1) and article 52 of Law number 40 of 2004 regarding the national social security, a social security organizing body must be established (Nuruli, R 2014).

Based on the result of research and theories which support, the authors argue that in its distribution, BPJS and General patients have similarities in obtaining ICU service facilities. Patients who have health insurance such as BPJS do not have problems in getting facilities in the ICU. In addition, PPK health care providers have followed the procedures established by Meranti Island District Hospital.

\section{The Distribution of General Patients in ICU Room in Regional Public Hospital of MERANTI ISLANDS DISTRICT}

Based on the results of research conducted at the Regional General Hospital of the Meranti Islands District, it is known that the distribution of the most general patients in the ICU room comes from high cliff subdistricts. In obtaining good service facilities for General Patients, the same BPJS \& SKTM is applied with no different. Patients are still served to get facilities in the ICU.

Based on the results of the study conducted by Nindita Agus Indriani (2013) stated that from the number of observations conducted, the result obtained that cash payment is the most widely used, which is as much as $40 \%$ of the total visits. This is due to the services using cash payments faster than other services because patients with cash payments do not require complete requirements when registering at TPPRJ, so that many patients prefer to pay in cash even though they have to pay for their own medical expenses without being paid by insurance.
The Distribution of ICU ROOM Patients according to SubDistricts in REgional Public hospital of Meranti IsLands DISTRICT

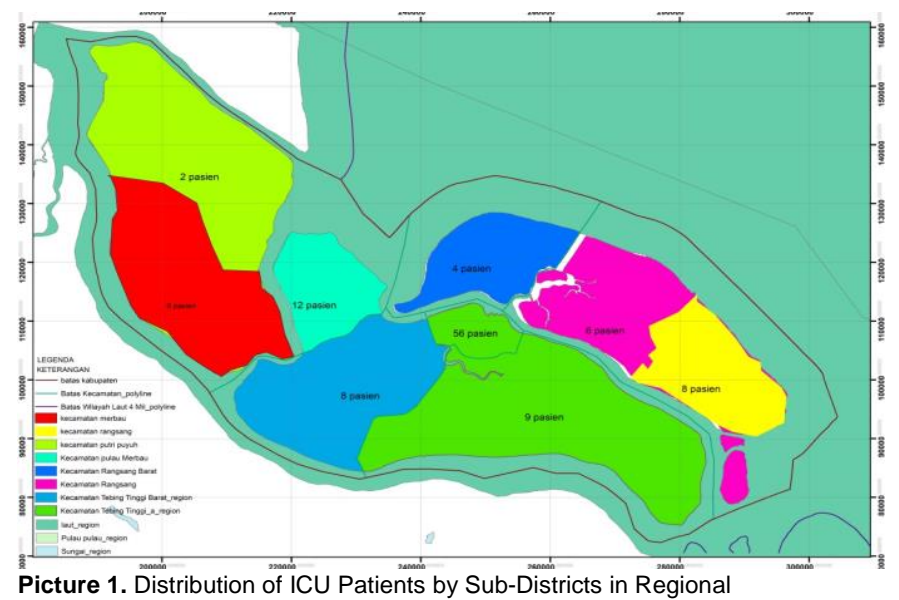

Based on the result of the study, it was found that the distribution of patients in the ICU room consisted of general patients, SKTM, BPJS, Jamkesda, and Employees. In obtaining ICU room facilities, there is no difference between the general patients and insurance patients, thus the treatment remains the same. In addition, the number of bed facilities available in the ICU is 4 patient beds.

Based on the results of the study conducted by Herianti (2015), it was stated that the making of thematic map on information on the distribution of the number of general patients admitted to NICU care in the yellow room was obtained from the data of patients entering the NICU in the yellow room in 2015. From this data, there were 1894 patients. The data is then sorted according to the payment method, and it is obtained as many as 941 patients who use their own fees or called as general patients. Data with a total of 941 patients recorded their respective addresses

Intensive Care Unit (ICU) in the Decree of the Minister of Health of the Republic of Indonesia Number: 1778 / MENKES / SK / XII / 2010 Intensive Care Unit (ICU) is a part of an independent Hospital (installation under the director of service), with specialized staff and equipment specifically for the treatment of patients suffering from lifethreatening illnesses, injuries or complications or potentially lifethreatening with dubious prognosis. ICU provides capabilities and facilities, infrastructure and special equipment to support vital functions by using the skills of medical staff, nurses and other staff who are experienced in managing these conditions

The Distribution of ICU room Patients According to Group Age in the form of Mapping in Regional Public Hospital of MERANTI ISLANDS DISTRICT

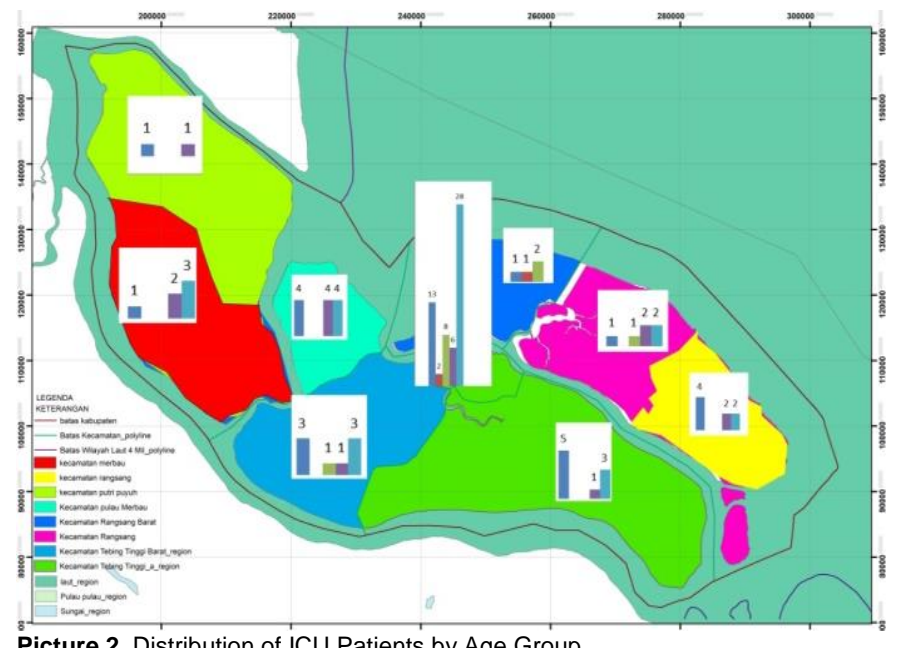

Picture 2. Distribution of ICU Patients by Age Group 
Based on the results of the research conducted, the distribution of ICU patients is based on the age group of patients treated in October 2017 until March 2018 in the ICU room from the age of 1 month to 80 years and above.

\begin{tabular}{ll} 
Tabel 2. The Group Age of ICU Patients \\
\hline Group Age Range & Number of Visit \\
\hline Toddler & 33 pasien \\
Children & 3 pasien \\
Teenager & 12 pasien \\
Adult & 19 pasien \\
Elder & 24 pasien \\
\hline
\end{tabular}

Age on the distribution of patients starts from toddlers, children, teenager, adults and the elderly including toddlers ( $0-5$ years), children (5-11 years), adolescents (12-25) years, adults (26-45 year) and elderly (46-65 years old)

\section{The Distribution of ICU Patients by Gender in the Form of} MAPPING IN MERANTI ISLANDS DISTRICT HOSPITAL

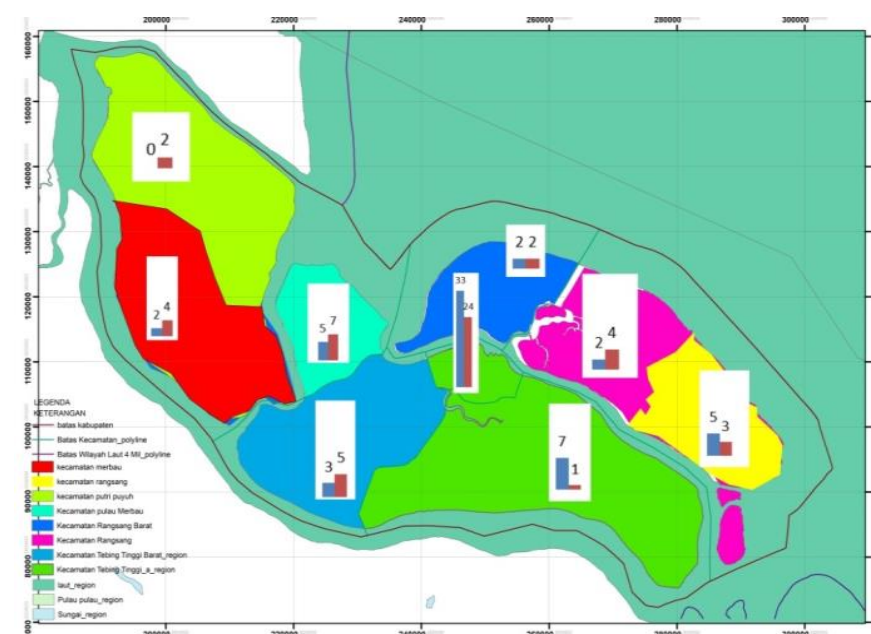

Picture 3. The Distribution of ICU Patients by Gender

Based on the results of research conducted at the Regional General Hospital of Meranti Islands District, it is known that for the distribution of ICU patients based on the highest gender in the Gender, patients who are often treated in the ICU are more male than female because male patients are more likely to be affected by the respiratory tract due to smoking.

Gender is same sex with the gender. It refers to biological differences between women and men; this biological difference is born from birth and cannot be changed. Gender is the difference in opportunities, roles, and responsibilities between men and women as a result of social construction in family life and community life. Gender = sociological term (sphare), Sex = biological term (sphare) (Joanne, 2014).

\section{CONCLUSION}

The distribution of BPJS patients in obtaining ICU service facilities has the same procedure as paying general patients and SKTM patients. The distribution of general patients in the ICU has the highest number of visits coming from high cliff sub-districts. In the period of October 2017 - March 2018, the number of visits of patients who had been treated was 3 patients. Distribution of ICU patients by sub-district on the number of visits October 2017 - March 2018 originating from 9 sub-districts consisting of Tebing Tinggi Sub-District, Tebing Tinggi Timur Sub-District, Tebing Tinggi Barat Sub-District, Rangsang SubDistricts, Rangsang Pesisir Sub-Districts, Rangsang Barat SubDistricts, Merbau Sub-District, Merbau Island Sub-District, and Tasik Putri Puyuh Sub-District. The distribution of ICU patients based on age group starts from toddlers, children, teenager, adult and the elderly. In addition, the highest number of age groups treated are as many as 44 patients. Meanwhile, from the distribution of ICU patients by gender, the highest patient visit is male.

\section{References:}

DepKes RI, (2006). Pedoman Penyelenggaraan dan Prosedur Rekam Medis Rumah Sakit Indonesia, Jakarta

Heriyanti. (2015). Pemetaan Penyebaran Pasien Umum Neonatal Intensive Care Unit (Nicu) Ruang Kemuning Tahun 2015 (Peta Tematik Di Rumah Sakit Anak Bunda Harapan Kita Provinsi Dki Jakarta)

Mayasari,I. (2016). Pemetaan distribusi kunjungan rawat inap di RSUD kabupaten brebes. Karya Tulis Ilmiah. Program Studi D3 RMIK, Pekanbaru.

Notoatmodjo,S. (2012). Metodologi Penelitian Kesehatan. Jakarta:Rineka Cipta Nuruli, R. (Ed). (2014). Memperoleh Jaminan Sosial dari BPJS Ketenagakerjaan. Jakarta Selatan: Tim Visi Yustisia

Najmah. (2015). Epidemiologi Untuk Mahasiswa Kesehatan Masyarakat. Jakarta: PT RajaGrafindo Persada

Pudyastuti, A.R, (2016). Pemetaan penyakit diare berbasis sistem informasi geografis di puskesmas tengaran. Karya Tulis Ilmiah. Program Studi D3 RMIK, Pekanbaru.

Rab, Tabrani. (2007). Agenda Gawat Darurat (Critical Care). Pekanbaru : P.T. Alumni.

Rustiyanti,E. (2010). Statistik rumah sakit untuk pengambilan keputusan. Yogyakarta: Graha ilmu

Staf Pemerintah Kota Banda Aceh. (2007). Modul Pelatihan ArcGis Tingkat Dasar. Banda Aceh: GIS Consorsium Aceh Nias

Tunggal, Hadi. (2010). Himpunan Undang-Undang Kesehatan \& Rumah Sakit. Jakarta: Havarindo

Indriani, N.A, (2013). Gambaran cakupan pelayanan rawat jalan melalui pemetaan jenis penyakit, alamat dan cara pembayaran pasien instalasi rawat jalan RSUD DR.M.ashari Kabupaten Pemalang tahun 2013.

Tangkudung, J.P.M (2014). Proses adaptasi menurut jenis kelamin dalam menunjang studi mahasiswa fisip universitas sam ratulangi 